PNL-7421

UC-602

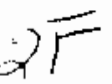

\title{
In Situ Vitrification of Soil from the Savannah River Site
}

\author{
B. E. Campbell \\ J. L. Buelt
}

August 1990

Prepared for the U.S. Department of Energy under Contract DE-AC06-76RLO 1830

Pacific Northwest Laboratory Operated for the U.S. Department of Energy by Battelle Memorial Institute 


\title{
DISCLAIMER
}

This report was prepared as an account of work sponsored by an agency of the United States Government. Neither the United States Government nor any agency thereof, nor Battelle Memorial Institute, nor any of their employees, makes any warranty, expressed or implied, or assumes any legal liability or responsibility for the accuracy, completeness, or usefulness of any information, apparatus, product, or process disclosed, or represents that its we would not infringe privately owned rights. Reference herein to any specific commercial product, process, or service by trade name, trademark, manufacturer, or otherwise, does not necessarily constitute or imply its endorsement, recommendation, or favoring by the United States Covernment or any agency thereof, or Battelle Meirorial institute. The views and opinions of authors expressed herein do not necessarily state or reflect those of the United States Government or any agency thereof.

\author{
PACIFIC NORTHWEST LABORATORY \\ operated by \\ BATTELLE MEMORIAL. INSTITUTE \\ for the \\ UNITED STATES DEPARTMENT OF ENERGY \\ under Contract DE-ACO6-76RLO 1830
}

Printed in the United States of America

Availabile to DOE and UOE contractors írom the

Ofíce of Scientific and Tedmical Information, P.O. Box 62, Oak Ridge, TN 37831; prices avaitable from (6:5) 576-B401. FTS 626-8401.

Available to the public from the National Technical Information Servire,

U.S. Departinent of Commerce, 528.5 Port koyal Rd., Springficld, VA 22161.

N BIS Price Codes, Microfiche A01

Printed Copy

\begin{tabular}{cr}
\hline Price Code & Page Range \\
\hline A02 & $1-10$ \\
A03 & $11-50$ \\
A04 & $51-75$ \\
A05 & $76-100$ \\
A06 & $101-125$ \\
A07 & $126-150$ \\
A08 & $151-175$ \\
A09 & $176-200$ \\
A10 & $201-225$ \\
A11 & $226-250$ \\
A12 & $251-275$ \\
A13 & $276-300$ \\
A14 & $301-325$
\end{tabular}

\begin{tabular}{cc}
\hline Price Code & Page Range \\
\hline A15 & $326-350$ \\
A16 & $351-375$ \\
A17 & $376-400$ \\
A18 & $401-425$ \\
A19 & $426-450$ \\
A20 & $451-475$ \\
A21 & $476-500$ \\
A22 & $501-525$ \\
A23 & $526-550$ \\
A24 & $551-575$ \\
A25 & $576-600$ \\
A99 & $601-U p$
\end{tabular}


PNL-7421

UC-602

IN SITU VITRIFICATION OF

SOIL FROM THE SAVANNAH RIVER SITE

\author{
B. E. Campbe11 \\ J. L. Buelt
}

August 1990

Prepared for

the U.S. Department of Energy

under Contract DE-AC06-76RL0 1830

Pacific Northwest Laboratory

Richland, Washington 99352 


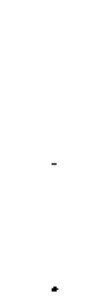




\section{SUMMARY}

Contamination associated with seepage basins and other underground structures at U.S. Department of Energy sites may be effectively remediated by application of in situ vitrification (ISV) technology. In situ vitrification converts contaminated soil and buried wastes into a giass and crystalline block, similar to obsidian commingled with crystalline phases. Two bench-scale tests performed at Pacific Northwest Laboratory (PNL)(a) in September 1989 demonstrated the feasibility of applying ISV to seepage basin soils at the Savannah River Site (SRS) in South Carolina. The two tests were performed on soils spiked with heavy metal and organic contaminants as well as stable radioactive simulants. These soils contain extremely low concentrations ( $<0.2 \mathrm{wt} \%$ ) of alkali fluxes such as sodium and potassium oxides, which are necessary charge carriers for the ISV process. Tests performed on the low flux-containing soil indicate the soil can be vitrified with special application of the ISV process. Tests showed the hazardous and radioactive simulants were successfully bound in the vitrified product and the organics were mostly destroyed. Additional larger scale testing and evaluation are recommended to further study the feasibility of treating contaminated SRS soil by the ISV process.

(a) Pacific Northwest Laboratory is operated for the U.S. Department of Energy by Batte1le Memorial Institute under Contract DE-ACO6-76RLO 1830. 



\section{ACKNOWLEDGMENTS}

The authors wish to thank Tom Powel1, Senior Technician at Pacific Northwest Laboratory, for his dedication and knowledge in completing these tests in an accurate and timely manner. 



\section{CONTENTS}

SUMMARY .............................

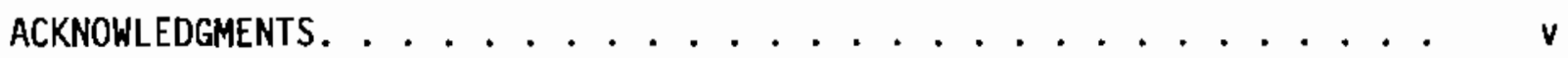

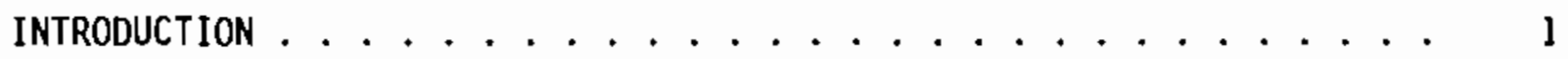

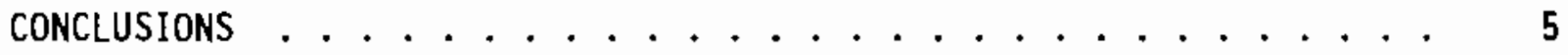

TEST DESCRIPTION ........................ 7

SOIL CHARACTERIZATION ........................ 7

TEST EQUIPMENT AND SETUP . . . . . . . . . . . . . . 9

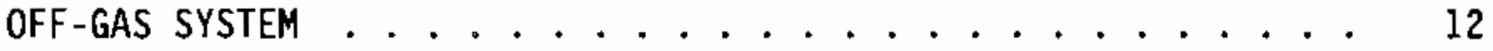

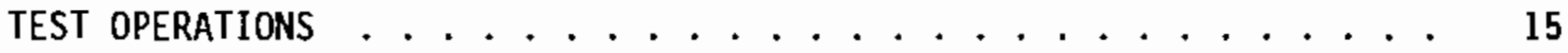

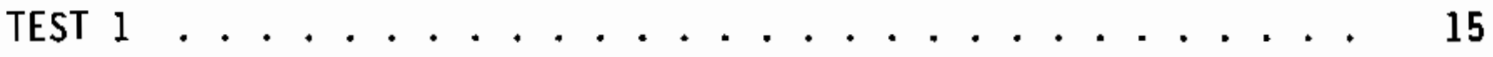

TEST $2 \ldots \ldots \ldots \ldots \ldots$

TEST RESULTS . . . . . . . . . . . . . . . . . 23

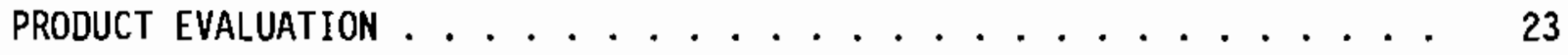

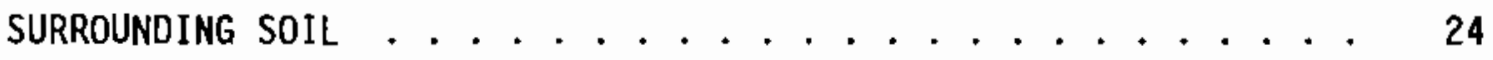

RETENTION OF RADIONUCLIDES AND HAZAROOUS CHEMICALS . . . . 25

POTENTIAL PROCESSING ENHANCEMENT TECHNIQUES FOR SRS SOILS $\ldots . \ldots 29$

REFERENCES ...................... 33 


\section{FIGURES}

1 The Process of In Situ Vitrification ............ 1

2 Containment for Bench-Scale Testing ............ 10

3 Schematic of Bench-Scale ISV Test Configuration ........ 11

4 Bench-Scale Sampling System ................ 13

5 ISV Processing of Simulated Contaminated SRS Soit . . . . . 16

6 SRS Bench-Scale Vitrified Block Prior to Removal, Test 1. . . . 16

7 SRS Bench-Scale Vitrified Block, Test 1........... 17

8 Electrical Data for ISV Processing of SRS Soil, Test 1. . . . . 19

9 SRS Bench-Scale Vitrified Block, Test 2 ......... 20

10 Electrical Data for ISV Processing of SRS Soil, Test 2. . . . . 21

11 The Effect of a Molten Metal "Passive" Electrode on Electrical Current Distribution in the Melt ........... 30

12 Melt Depth Versus Energy Input for Three Bench-Scale ISV Tests . . . . . . . . . . . . . . . . 31

\section{TABLES}

1 Testing Units for Developing ISV Technology .......... 2

2 Concentrations of Radionuclide Simulants and Hazardous

Components in the Simulated Contaminated SRS Soil ....... 8

3 Composition of Uncontaminated SRS Soil ........... 9

4 EP Tox Concentrations for the SRS Bench-Scale Tests ....... 23

5 Surrounding Soil Analyses.................. 24

6 Contaminant Retention in the Vitrified Soil ......... 26

7 Decontamination Factors of Metals . . . . . . . . . 27 


\section{INTRODUCTION}

Pacific Northwest Laboratory(PNL) (a) has completed a test of the In Situ Vitrification (ISV) process on soils from the Savannah River Site (SRS) in South Carolina. In situ vitrification is an in-place, soil-melting process that converts contaminated soils and sludges into a glass and crystalline product similar to obsidian commingled with crystalline phases. The ISV product is potentially delistable under the Resource Conservation and Recovery Act (RCRA), while the process also converts characteristic, dangerous chemical wastes into an unregulated, relatively inert and nonleachable product. At the same time, it immobilizes radioactive constituents associated with the soil or sludge by incorporating them into the inert product, isolating them for geologic periods of greater than one million years (Buelt et al. 1987).

Figure 1 illustrates the ISV process. A square array of four molybdenum electrodes is inserted into the ground to the desired treatment depth. Because soil is not electrically conductive when the moisture has been driven off, a conductive mixture of flaked graphite and $\mathrm{glass}$ frit is placed among the electrodes to act as a starter path. An electrical potential is applied

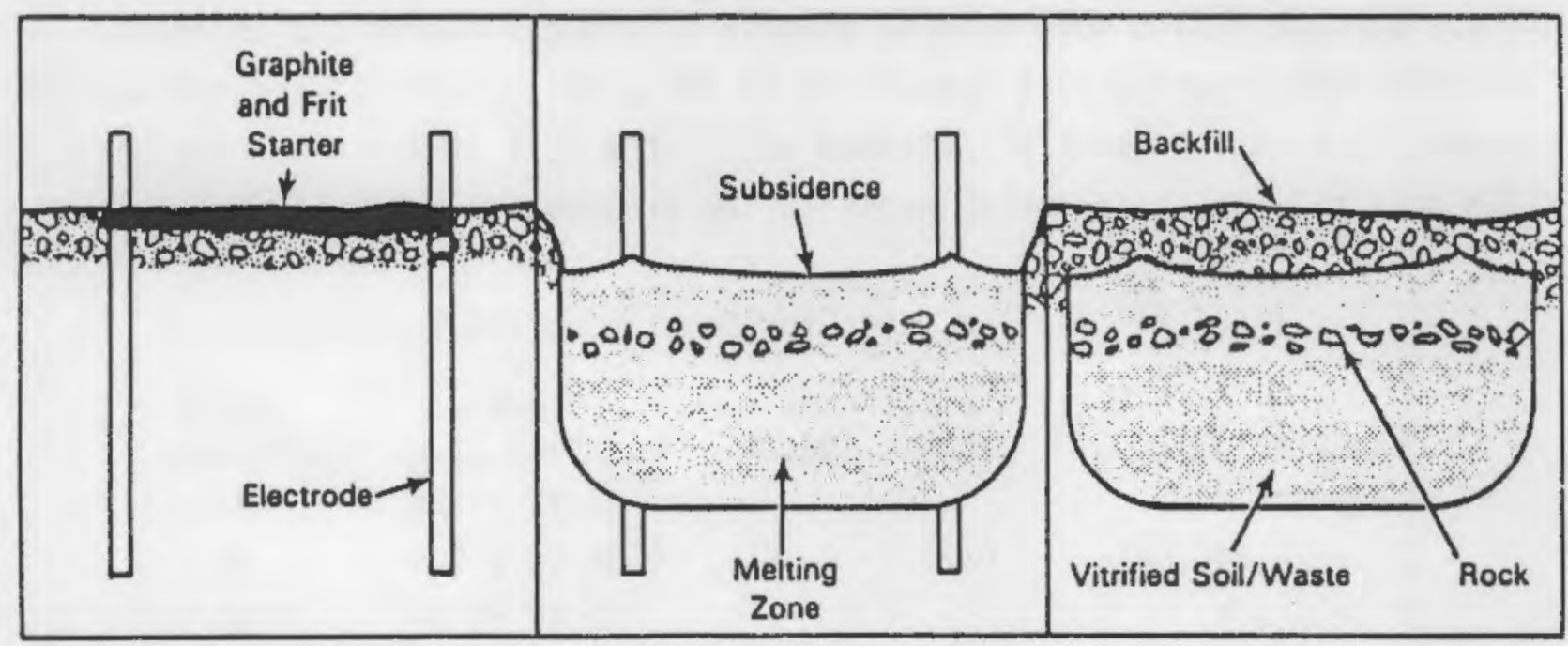

FIGURE 1. The Process of In Situ Vitrification

(a) Pacific Northwest Laboratory is operated by Battelle Memorial Institute for the U.S. Department of Energy under Contract DE-AC06-76RLO 1830. 
potential is applied to the electrodes to establish an electrical current in the starter path. The resultant power heats the starter path and surrounding soils to $1600^{\circ} \mathrm{C}$ to $2000^{\circ} \mathrm{C}$, well above initial soil-melting temperatures of $1100^{\circ} \mathrm{C}$ to $1400^{\circ} \mathrm{C}$. The graphite starter path is eventuallyconsumed by oxidation, and the current is transferred to the molten soil, which is electrically conductive. As the molten or vitrified zone grows, it incorporates radionuclides and nonvolatile hazardous elements, such as heavy metals, into the glass structure and destroys organic components by pyrolysis. The pyrolyzed byproducts migrate to the surface of the vitrified zone, where they combust in the presence of oxygen. A hood placed over the area being vitrified directs the gaseous effluents to an off-gas treatment system.

Since PNL began developing the ISV technology, numerous experimental tests with a variety of conditions and waste types have been conducted. Table 1 describes the different scales of testing units that PNL used in developing ISV technology. The successful results of the bench-, engineering-, pilot-, and large-scale tests have demonstrated the feasibility of the process.

Various seepage basins exist at the Savannah River Site (Odum et al. 1987, Dunaway et a1. 1987, Pekkala et a1. 1987a, and Pekkala et a1. 1987b). These seepage basins were used to dispose of process wastes and decontamination wastes during past operations of the plant. Chemical and radioactive constituents are presently contained within the soil of these seepage basins. The proximity of these contaminants to the groundwater makes it desirable to

\section{TABLE 1. Testing Units for Developing ISV Technology}

\begin{tabular}{|c|c|c|c|}
\hline Equipment Size & $\begin{array}{l}\text { Electrodes } \\
\text { Separation, m }\end{array}$ & $\begin{array}{l}\text { Block } \\
\text { Size }\end{array}$ & $\begin{array}{c}\text { Tests } \\
\text { Completed (a) }\end{array}$ \\
\hline Bench-Scale & .1 & 1 to $10 \mathrm{~kg}$ & 19 \\
\hline Engineering-Scale & 0.23 to 0.36 & 0.05 to $1.0 \mathrm{t}$ & 33 \\
\hline Pilot-Scale & 1.2 & 10 to $50 \mathrm{t}$ & 17 \\
\hline Large-Scale & 3.5 to 5.5 & 400 to $800 \mathrm{t}$ & 5 \\
\hline
\end{tabular}

(a) As of $1 / 26 / 90$. 
better immobilize the contaminants into a vitrified product. Typical contaminants in these seepage basins include the following:

$\begin{array}{llll}\text { arsenic } & \text { nitrates } & \text { methylene chloride } & \text { cobalt-60 } \\ \text { barium } & \text { lead } & \text { dichloro-difluoro methane } & \text { strontium-90 } \\ \text { cadmium } & \text { silver } & \text { bis (2-ethylhexyl) phthalate } & \text { cesium-137 } \\ \text { chromium } & & & \text { americium-241 } \\ \text { mercury } & & & \text { tritium }\end{array}$

The objective of this study was to determine the feasibility of vitrifying Savannah River soil spiked with chemicals that represent typical contaminants expected in the seepage basins. Feasibility was determined by analyzing the results of two bench-scale tests. Analysis of the test results reveals insights into the processability of the Savannah River soils, process behavior of the contaminants (i.e., retention in the vitrified product and the degree of destruction of the organic constituents), and product durability. This report presents the findings from these bench-scale tests. 



\section{CONCLUSIONS}

Two bench-scale tests conducted by PNL in September 1989 have investigated and demonstrated the feasibility of using ISV to remediate contaminated seepage basin soil at the Savannah River Plant. The tests investigated two different applications of the ISV process to the alkali-depleted soil located at and around the SRS facility. Simulated contaminated soil was used in both tests with contaminant concentrations determined by actual field conditions or minimum analytical detection levels, whichever was higher. The following conclusions are based on analyses of the ISV processing test behavior and of the vitrified products.

- The low alkali-containing soil present at SRS can be vitrified using the ISV process if special enhancement techniques are used. The technique of pre-mixing the alkali-depleted soils with $\mathrm{Na}_{2} \mathrm{CO}_{3}$ was successfully demonstrated in this study. Special applications of the process are identified in this report and should be tested to verify the in situ capability of the ISV process is retained for treating alkali-depleted soils.

- No significant transport of hazardous constituents to the surrounding soil was observed. Residual contaminant concentrations in the surrounding soil after processing were far below those for regulated wastes.

- Samples of the ISV-generated glass from Tests 1 and 2 that were subjected to Extraction Procedure Toxicity (EP TOX) testing each produced leach concentrations significantly below the U.S. Environmental Protection Agency (EPA) limits. 



\section{TEST DESCRIPTION}

The pretest soil characterization, the bench-scale test equipment and setup, and the off-gas system used for the tests are described in this section. The test was conducted using the bench-scale test equipment located in the Engineering Development Laboratory at Hanford.

\section{SOIL CHARACTERIZATION}

Soil characterization determined the concentrations of the simulated contaminants used in the tests and the composition of the uncontaminated SRS soil. Of interest was the ability of the ISV process to treat SRS soil containing radionuclides and hazardous chemical materials. To maximize the applicability of the data produced from this test, analyses of the contents of SRS seepage basins were reviewed for typical contaminants. Maximum concentrations of hazardous cations and anions, as well as radioactive species, were identified. These concentrations were compared with projected minimum detectable concentrations in the ISV block, soil, and off gas, and the highest of these four values was selected. The objective was to select soil compositions that would present the most challenge to ISV and simulate potential conditions at the site. Table 2 lists the components and their concentrations in the simulated soil. Stable forms of the radioactive species were used in this test to simulate radioactive species. Hazardous cations such as arsenic, barium, cadmium, chromium, mercury, and lead may be found to be present in the seepage basin soils and were, therefore, tested.

Pretest sampling of the uncontaminated SRS soil was performed to identify the presence of any hazardous components. No significant concentrations of contaminants were found. This sampling also determined the presence and quantity of glass-forming materials (i.e., $\mathrm{SiO}_{2}$ and $\mathrm{Al}_{2} \mathrm{O}_{3}$ ) and fluxes (i.e., $\mathrm{Na}_{2} \mathrm{O}, \mathrm{K}_{2} \mathrm{O}$, and $\mathrm{CaO}$ ) that would contribute to proper melting at the ISV process temperature range of $1200^{\circ} \mathrm{C}$ to $2000^{\circ} \mathrm{C}$ (Table 3). The analysis confirms actual Savannah River Site soil characterizations (Looney et al. 1990) of the soil being severely depleted of alkali elements $\left(<0.2 \mathrm{wt} \% \mathrm{Na}_{2} \mathrm{O}\right.$ and $\left.\mathrm{K}_{2} \mathrm{O}\right)$. These elements are necessary to conduct electrical energy during processing 
TABLE 2. Concentrations of Radionuclide Simulants and Hazardous Components in the Simulated Contaminated SRS Soil

\begin{tabular}{|c|c|c|}
\hline $\begin{array}{l}\text { Inorganic } \\
\text { Component }\end{array}$ & Form Added & Concentration, ppm \\
\hline As & $\mathrm{As}_{4} \mathrm{O}_{6}$ & 5 \\
\hline $\mathrm{Ba}$ & $\mathrm{BaSO}_{4}$ & 310 \\
\hline Cd & $\mathrm{Cd}\left(\mathrm{NO}_{3}\right)$ & 210 \\
\hline $\mathrm{Ce}$ & $\mathrm{CePO}_{4}$ & 2700 \\
\hline Cs & $\mathrm{CsNO}_{3}$ & $4^{50}$ \\
\hline $\mathrm{Cl}$ & $\mathrm{NaCl}$ & 310 \\
\hline $\mathrm{Cr}$ & $\mathrm{Cr}_{2} \mathrm{O}_{3}$ & 2500 \\
\hline Co & $\mathrm{Co}\left(\mathrm{NO}_{3}\right)_{2} 6 \mathrm{H}_{2} \mathrm{O}$ & 450 \\
\hline $\mathrm{Cu}$ & $\mathrm{CuSO}_{4}$ & $1_{190}$ \\
\hline $\mathrm{CN}$ & $\mathrm{KCN}$ & 15 \\
\hline $\mathrm{F}$ & $\mathrm{NaF}$ & 3 \\
\hline $\mathrm{Pb}$ & $\mathrm{Pb}$ shavings & 320 \\
\hline $\mathrm{Hg}$ & $\mathrm{HgO}$ & 60 \\
\hline $\mathrm{Ni}$ & $\mathrm{NiSO}_{4} 6 \mathrm{H}_{2} \mathrm{O}$ & 370 \\
\hline $\mathrm{Ag}$ & $\mathrm{AgNO}_{3}$ & 40 \\
\hline $\mathrm{Sr}$ & $\mathrm{Sr}\left(\mathrm{NO}_{3}\right)_{2}$ & 4500 \\
\hline $\mathrm{NO}_{3}$ & various & 1700 \\
\hline $\mathrm{PO}_{4}$ & $\mathrm{Ce}(\mathrm{PO} 4)$ & 1800 \\
\hline $\mathrm{SO}_{4}$ & various & 1100 \\
\hline \multicolumn{2}{|c|}{ Organic, Component } & Concentration, $\mathrm{ppm}$ \\
\hline \multicolumn{2}{|c|}{$\begin{array}{l}\text { Bis (2-ethylhexy1) } \\
\text { Phthalate }\end{array}$} & 340 \\
\hline \multicolumn{2}{|c|}{ Methylene Chloridel } & 70 \\
\hline
\end{tabular}

and help lower melting temperatures. The minimum combined alkali concentration previously determined to be necessary for vitrification of soils using the ISV process is approximately $1.4 \mathrm{wt} \%$ (Buelt et al. 1987). This concentration represents the actual alkali content of soil from Maxey $\mathrm{Flats}$ Kentucky, which had been previously analyzed to determine soil property 
TABLE 3. Composition of Uncontaminated SRS Soil

\begin{tabular}{lc} 
Component & $\begin{array}{c}\text { Normalized } \\
\text { Dry Basis, wt\% }\end{array}$ \\
\cline { 1 - 1 } $\mathrm{Al}_{2} \mathrm{O}_{3}$ & 4.8 \\
$\mathrm{CaO}$ & 0.4 \\
$\mathrm{Fe}_{2} \mathrm{O}_{3}$ & 0.77 \\
$\mathrm{~K}_{2} \mathrm{O}$ & 0.13 \\
$\mathrm{MnO}_{2}$ & 0.01 \\
$\mathrm{Na}_{2} \mathrm{O}$ & 0.05 \\
$\mathrm{P}_{2} \mathrm{O}_{5}$ & 1.12 \\
$\mathrm{SiO}_{2}$ & 92.5 \\
$\mathrm{SrO}^{2}$ & 0.001 \\
$\mathrm{TiO}_{2}$ & 0.4 \\
$\mathrm{ZrO}_{2}$ & 0.09 \\
$\mathrm{Total}^{2}$ wt\% Oxide & 100.0
\end{tabular}

characteristics and found to be fluid at temperatures of $2000^{\circ} \mathrm{C}$ or less. Therefore, a special process technique was implemented during the first test to vitrify the alkali-depleted soil. This technique is described in the following section.

\section{IEST EOUIPMENT AND SETUP}

The PNL bench-scale unit consists of a 208-L (55-gal) drum, which contains the soil to be vitrified, placed in a $1.8-\mathrm{m}(6-\mathrm{ft})$ diameter by $2.4-\mathrm{m}$ (8-ft) tall sealed chamber (Figure 2). Two molybdenum and graphite cylindrical electrodes are buried $10 \mathrm{~cm}$ ( 4 in.) apart down to the desired depth of vitrification. The simulated contaminated zone consisted of $2.2 \mathrm{~kg}$ of chemically spiked soil arranged in a 8 -cm-wide by $17-\mathrm{cm}$-long oval shape, extending to a depth of $12.5 \mathrm{~cm}$. Figure 3 diagrams the setup for the bench-scale test. For this test, uncontaminated SRS soil was used to surround the simulated contaminated zone. The containment module is capable of operation at a slightly negative pressure to contain and sample off gases generated during the process. The off gases from the vitrified area can be continuously sampled throughout the test. The test was conducted using two $1.3-\mathrm{cm}$ 


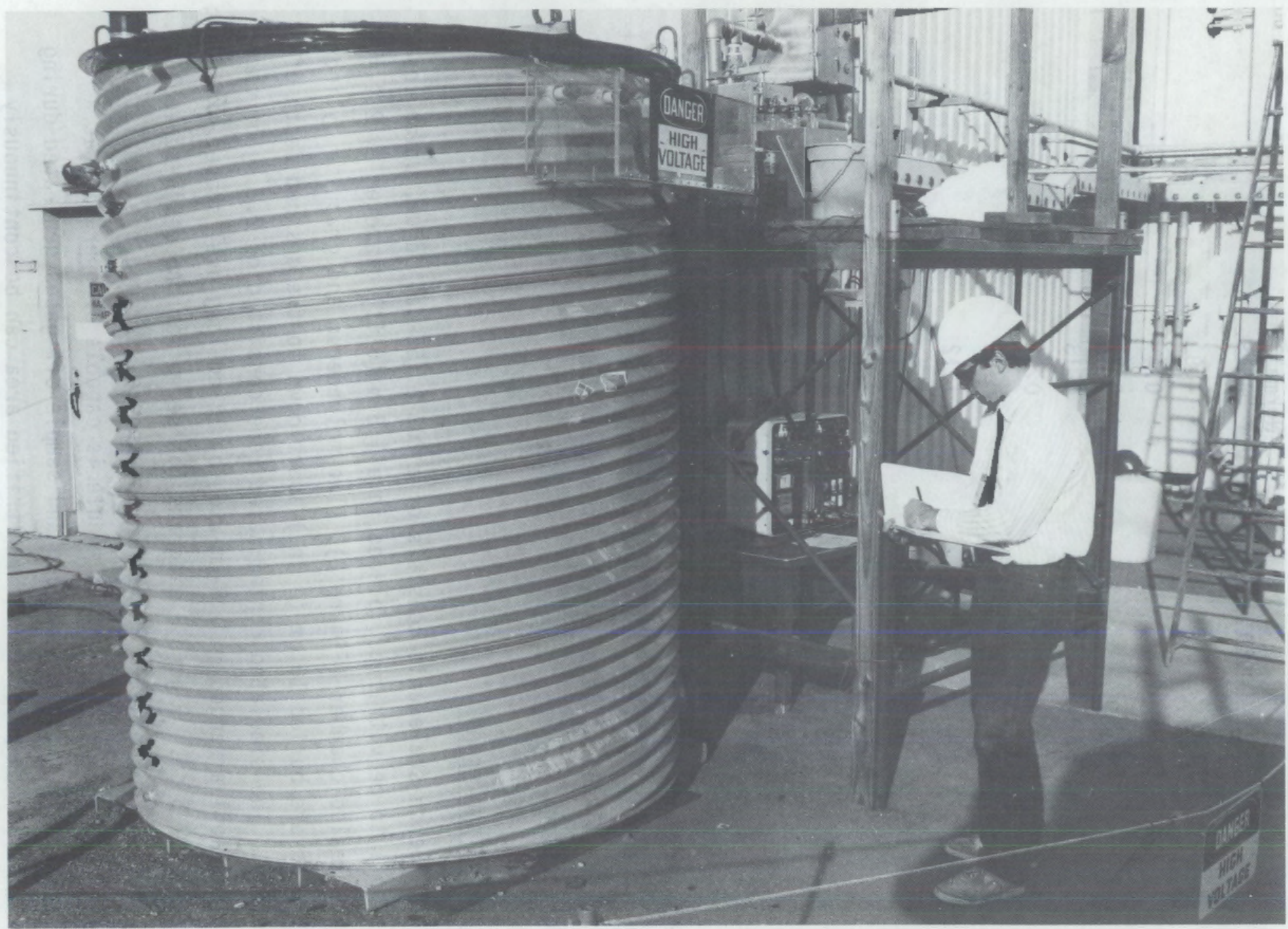

FIGURE 2. Containment for Bench-Scale Testing 


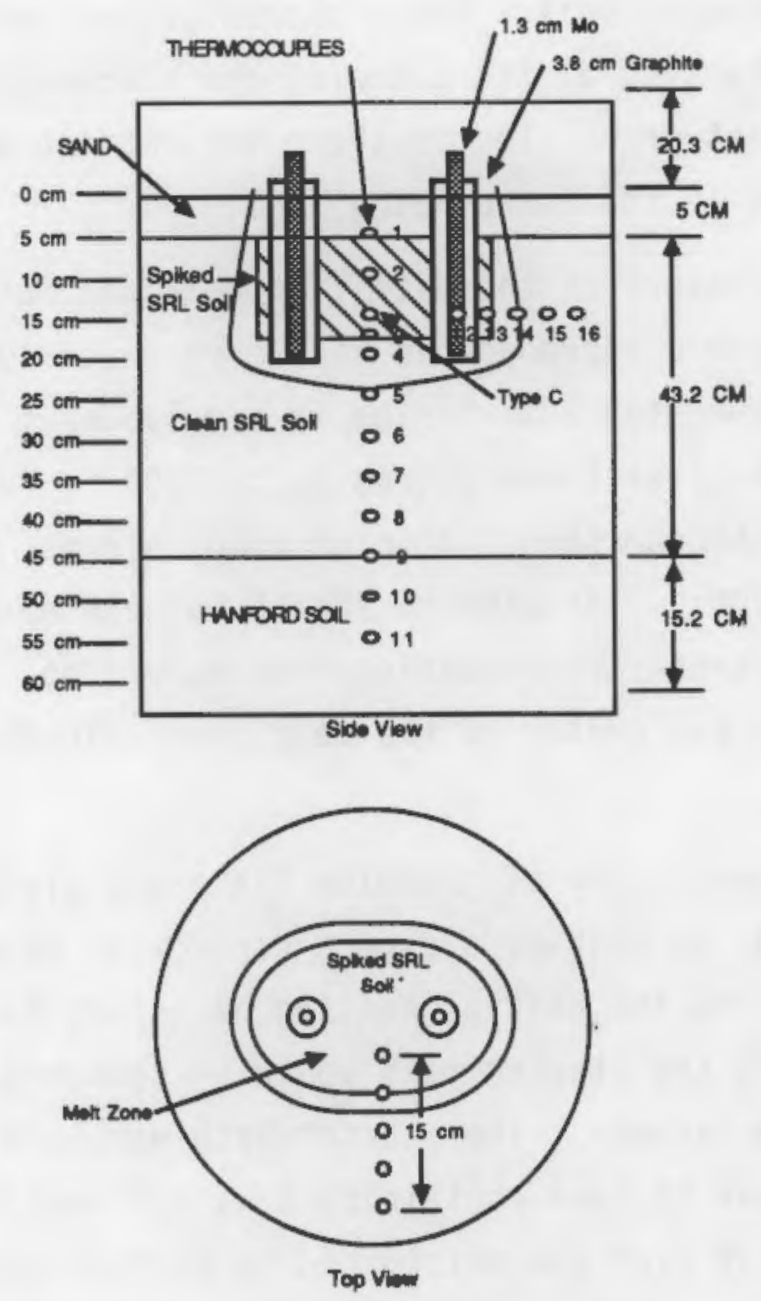

FIGURE 3. Schematic of Bench-Scale ISV Test Configuration

(0.5-in.) diameter molybdenum electrodes. A 3.8-cm (1.5-in.) graphite collar was placed over the molybdenum electrode to prevent excessive oxidation that could otherwise occur at the interface of the oxygen-containing hood environment and the molten soil. Fixed electrodes buried to a depth of $20 \mathrm{~cm}(8-\mathrm{in}$.) were used in this test.

Thermocouples were installed vertically in the center of the test drum and horizontally at the tank midpoint to monitor the melt shape. Type $K$ thermocouples were used, which possess a maximum temperature limit of $1400^{\circ} \mathrm{C}$. The upper vertical Type $K$ thermocouple was placed $5 \mathrm{~cm}(2 \mathrm{in.})$ below the soil surface and then at $5-\mathrm{cm}\left(2-\mathrm{in}_{\text {. }}\right)$ intervals to a depth of $55 \mathrm{~cm}$ (22 in.). In addition, five Type $K$ thermocouples were placed at the $15-\mathrm{cm}(6-\mathrm{in}$.$) depth to$ 
surrounding uncontaminated soil. These thermocouples were spaced at $5-\mathrm{cm}$ (2-in.) intervals, starting at the plane of the electrode array and moving out to the edge of the test drum. The isotherm information was used to determine locations for samples in the surrounding soil.

The actual temperature of the vitrified melt was monitored using a Type $C$ thermocouple. A Type $C$ thermocouple is a more expensive junction of tungsten-5\% rhenium and tungsten-26\% rhenium in a molybdenum sheath. It is capable of reading molten glass temperatures up to $2300^{\circ} \mathrm{C}$, but because of rapid oxidation of the molybdenum sheath at high temperatures, it has a limited service life above $1700^{\circ} \mathrm{C}$. An alumina sheath was placed over the Type $\mathrm{C}$ thermocouple to prevent excessive oxidation from occurring. The Type $\mathrm{C}$ thermocouple was located in the center of the melt area, directly between the electrodes.

A starter path consisting of graphite flake and glass frit was laid between the electrodes to provide a direct conductive path. The starter path was necessary to provide the initial heating necessary to begin the melting process, at which time the starter path would be consumed and the molten soil become the conductive pathway. The starter path was laid in a $6-\mathrm{cm}-$ (2.44-in.-) thick layer of sand containing 5 wt\% of combined $\mathrm{Na}_{2} \mathrm{O}$ and $\mathrm{K}_{2} \mathrm{O}$. The $6-\mathrm{cm}$-thick layer of sand was determined to be thin enough to create locally high temperatures between the electrodes and begin to vitrify the higher melting SRS soil below. One of the objectives of the bench-scale test was to determine the effectiveness of this starter layer technique.

The power system used in this bench-scale test consisted of a singlephase 10-kW capacity transformer. The transformer contained five voltage taps and was wired for primary control with a silicon-controlled rectifier. The test was set to run at a target control power of $5 \mathrm{~kW}$ to more closely match power densities anticipated for the large-scale system.

\section{OFF-GAS SYSTEM}

The off-gas sampling system was designed to collect particulates and volatile compounds present in the spiked SRS soil. The sampling train used in this test was an approved modification of EPA Method 5 consisting of a heated glass fiber filter, two $500-\mathrm{mL}$ gas impingers, a silica gel bed, a 
heated glass fiber filter, two $500-\mathrm{mL}$ gas impingers, a silica gel bed, a vacuum pump, a flow meter, and a wet test meter (Figure 4). A portion of the total off-gas stream was isokinetically drawn through the sampling system and then piped back to the ISV system off gas. Sampling of the off-gas stream for methylene chloride and bis (2-ethylhexy1) phthalate was performed periodically throughout the test, using component-specific sampling columns.

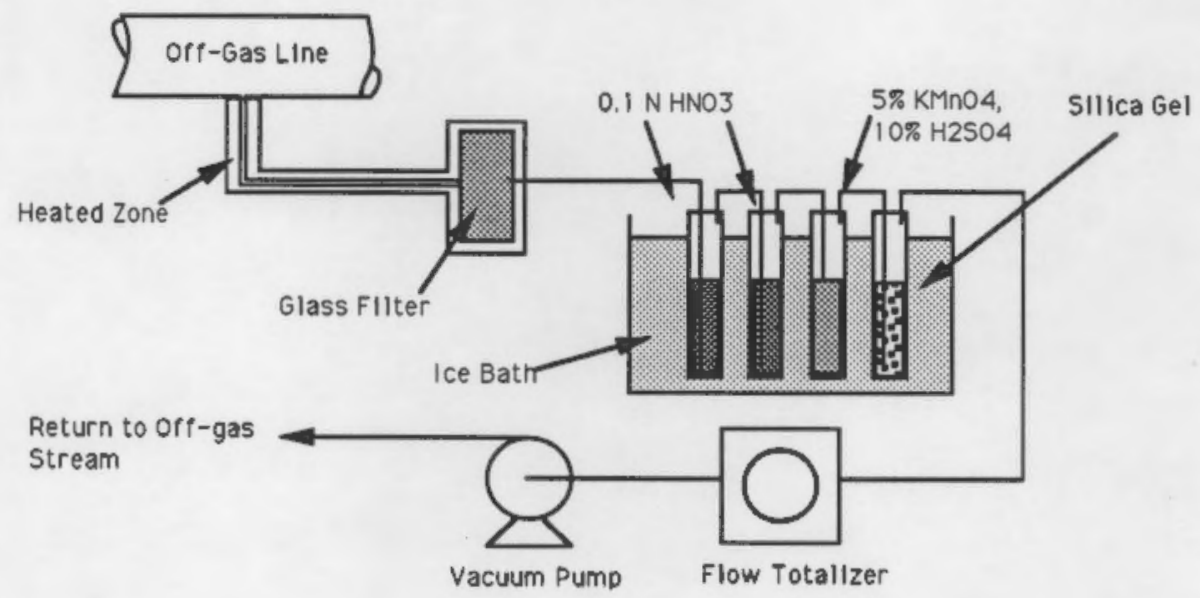

FIGURE 4. Bench-Scale Sampling System 



\section{IEST OPERATIONS}

Two bench-scale tests were performed to determine the applicability of ISV in treating contaminated SRS seepage basins. The first test used a $6-\mathrm{cm}$ (2.4-in.) layer of sand over the contaminated SRS soil to promote startup. Studies performed to determine melt properties of the SRS soil indicated the soil typically fused at a temperature greater than $1625^{\circ} \mathrm{C}$, which is due primarily to the low concentration of alkali flux materials present in the SRS soil. The 6-cm (2.4-in.) depth for the sand cover layer was selected to minimize outward growth on the surface due to the lower melting point of the sand, while still possessing enough alkali material (charge-carrying ions) to promote downward melting through the contaminated zone. The flux material contained in the sand was mixed with the SRS soil by the natural mixing behavior of the ISV process in conjunction with the two soils having similar viscosities once molten. In addition, the sand layer provided an even media to lay the starter path so that a smooth startup of the process occurred.

The second test involved excavating a 3-kg portion of the SRS soil and mixing $5 \mathrm{wt} \%$ of $\mathrm{Na}_{2} \mathrm{CO}_{3}$ on an oxide basis uniformly throughout the soil. This was intended to represent soil conditions that have been successfully treated by ISV. This technique, although not optimum, is achievable on larger scales and on actual contaminated waste sites by various application techniques.

\section{IEST 1}

This test involved using the test configuration previously described in this report. After initial startup was achieved, the test continued for $4.2 \mathrm{~h}$ at which time a failed electrode caused the premature shutdown of the test. A total energy of $25.1 \mathrm{kWh}$ was input into the soil forming a $6.4-\mathrm{kg}$ block. Figure 5 is a photograph showing the process during operation of Test 1 . The resultant vitrified block as seen in the test containment is shown in Figure 6 .

Thermocouple data gathered during the test indicated that melting occurred $5 \mathrm{~cm}(2$ in.) down into the contaminated soil region prior to failure of the electrode. The intended depth of vitrification for this test was $20 \mathrm{~cm}$ $(7.9 \mathrm{in})$. The $\mathrm{flat}$, rounded shape of the upper portion of the block is due to 


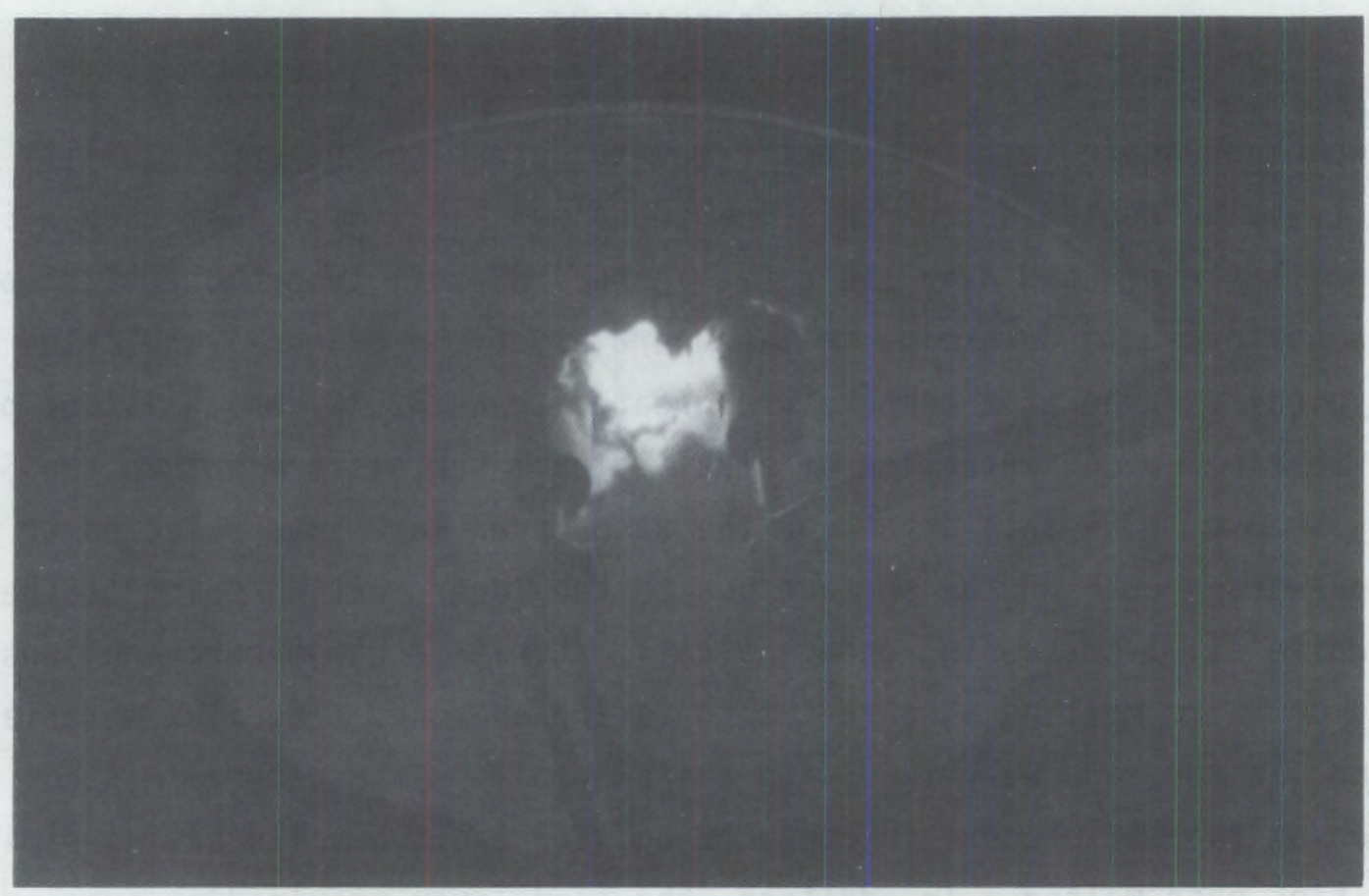

FIGURE 5. ISV Processing of Simulated Contaminated SRS Soil



FIGURE 6. SRS Bench-Scale Vitrified Block Prior to Removal, Test 1 
the dissimilar melting point of the two soils causing preferential melting of the sand placed on the surface. The vitrified material below the upper flat area was determined to be a region of $g l$ ass composed of a mixture of contaminated SRS soil and sand (Figure 7). The mixture was created by the natural convection of the process, so the technique was partially successful.

Dissection of the vitrified block revealed a slightly discolored glass located between the electrodes. This confirms that some of the contaminated soil had been incorporated into the block. A material balance performed on the silica concentrations of the glass and the two soils indicated the block was composed of $25 \mathrm{wt} \%$ SRS soil. Continued operation of the test would have incorporated additional SRS soil into the block. However, the extremely high operating temperatures $\left(>1700^{\circ} \mathrm{C}\right)$ greatly increased the rate of oxidation occurring at the electrodes. Measures taken to protect the molybdenum electrodes, such as placing the outer graphite collars higher on the molybdenum, would have slowed the effects of oxidation on the electrodes.

The power data from the test indicate a rapid startup with very little power fluctuations. The fluctuations that were present were caused by arcing that occurs between the graphite particles in the starter path. This type of

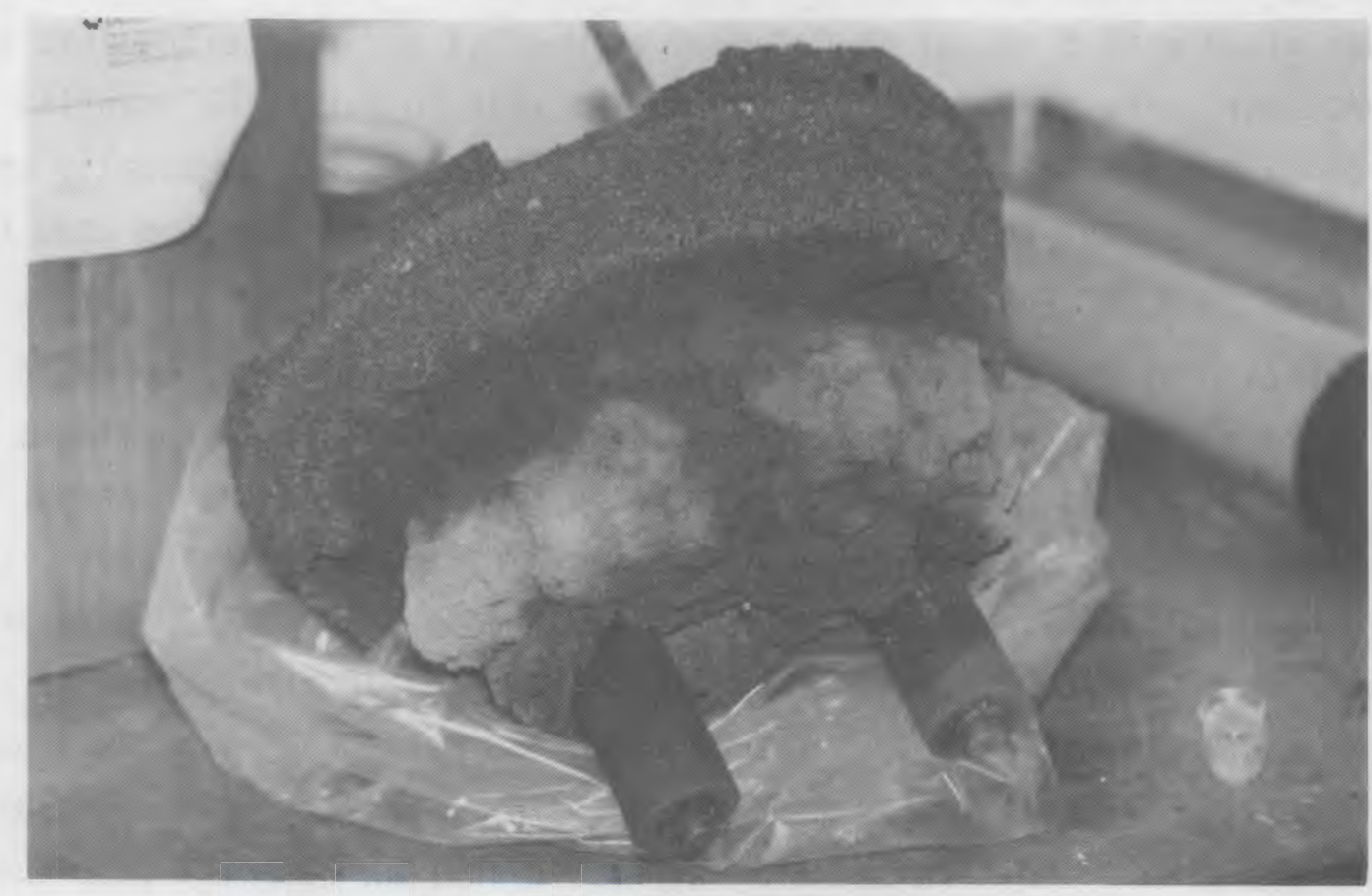

FIGURE 7. SRS Bench-Scale Vitrified Block, Test 1 
arcing disappears as the starter path is consumed. The power curve indicates a rapid rise to the operating power level of $5 \mathrm{~kW}$ with a balanced control after $1 \mathrm{~h}$ of operation. This is explained by the preferential melting of the cover sand, which is known to melt easily and provide sufficient amounts of charge-carrying ions in the molten soil. The power data for Test 1 is presented in Figure 8 . The consumption of the starter path can be seen in the power curves as an increase in the resistance as soil begins to melt and the path is consumed. As the more resistive soil begins to melt, a decrease in amperage to the melt is seen; however, as the resistance of the melt decreases, the amount of current is increased to provide additional heating.

A $2.5-\mathrm{cm}$ (1-in.) subsidence was observed at the surface of the melt, which is caused by the densification of the soil as it becomes molten.

\section{IEST 2}

After the completion of Test 1 , the vitrified block was removed from the test container. The remaining unvitrified contaminated soil was removed from the container so that new electrodes and thermocouples could be placed. In addition, the unvitrified contaminated soil (approximately $3 \mathrm{~kg}$ due to some surrounding soil being excavated along with the unvitrified contaminated soil) was mixed with $5 \mathrm{wt} \%$ of $\mathrm{Na}_{2} \mathrm{O}$ (added as $\mathrm{Na}_{2} \mathrm{CO}_{3}$ ) and reinserted into the test container. The $\mathrm{Na}_{2} \mathrm{O}$ was added to the SRS soil to match the quantity of alkali contained in the sand. The test setup was completed identically to Test 1 with the exception of a smaller $2.5-\mathrm{cm}(1-\mathrm{in}$.$) layer of sand used to$ form an even path for the starter material.

Completion of the test to the desired depth of $20 \mathrm{~cm}$ was achieved in $2.4 \mathrm{~h}$. A total of $7.4 \mathrm{kWh}$ of energy was input into the soil in forming a $7.7-\mathrm{kg}$ block, achieving a mass-to-energy ratio of $1.0 \mathrm{~kg}$ soil/ $\mathrm{kWh}$ energy. The vitrified block produced in Test 2 is shown in Figure 9. The power, current, voltage potential, and melt resistance curves are shown in Figure 10. This test, in comparison to Test 1 , demonstrated a longer time period to reach the control power. The resistance curve indicates the melt remained at a higher resistance for a longer time period. This would indicate the SRS soil with the alkali addition was slightly lower in flux material than the sand used in the previous test. However, since the entire contaminated 

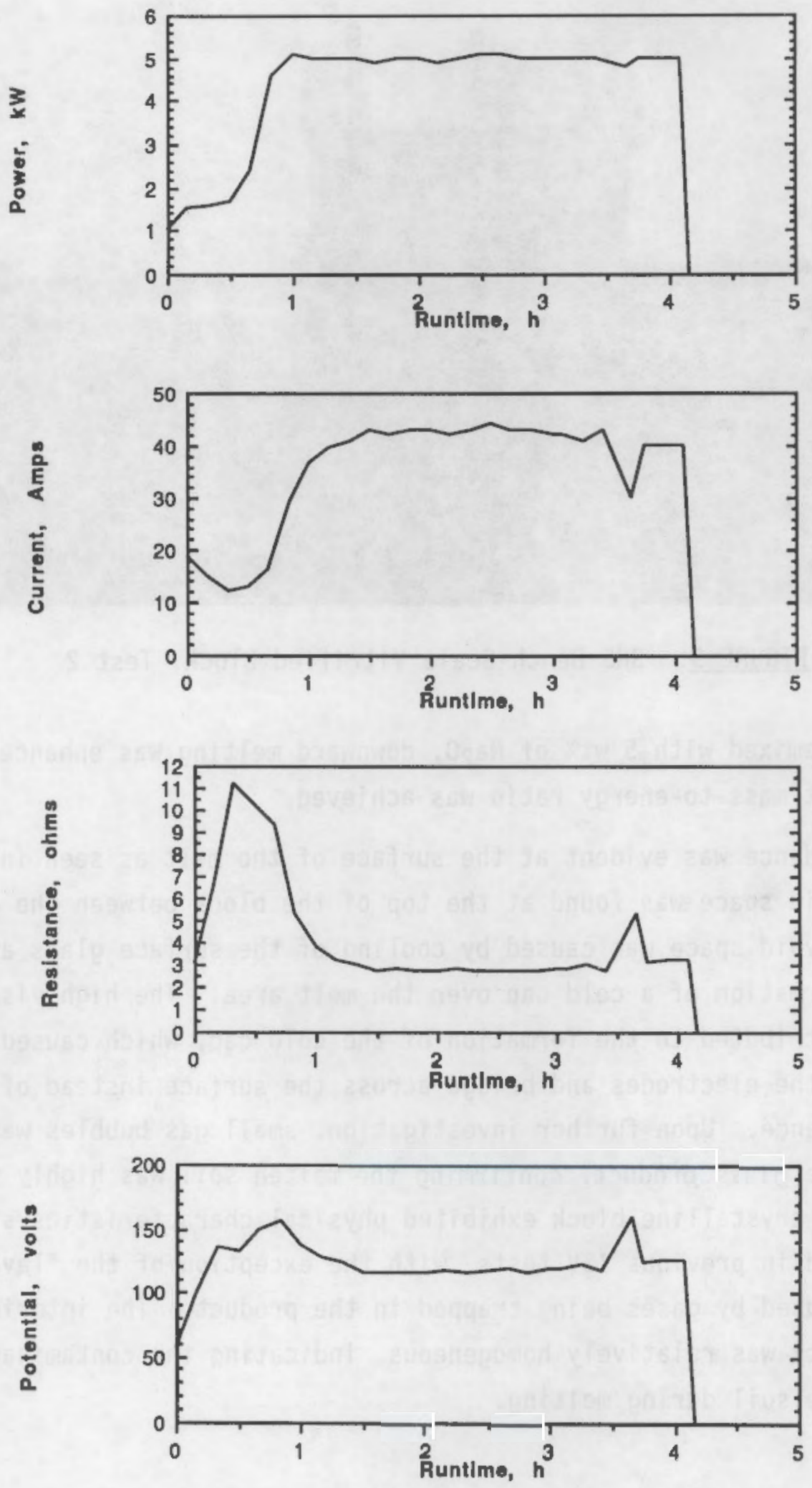

FIGURE 8. Electrical Data for ISV Processing of SRS Soil, Test I 


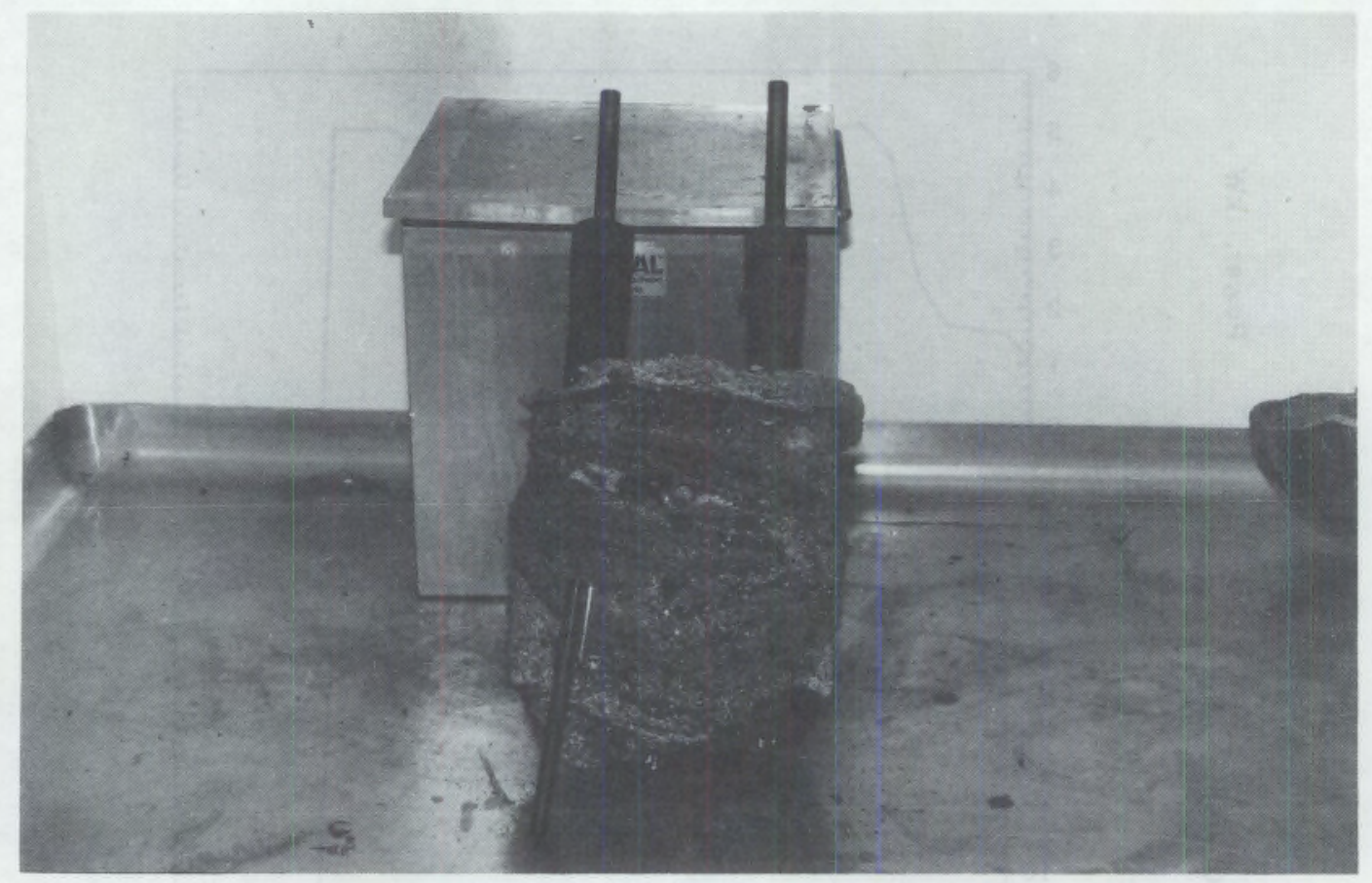

FIGURE 9. SRS Bench-Scale Vitrified Block, Test 2

region was premixed with 5 wt\% of $\mathrm{Na}_{2} \mathrm{O}$, downward melting was enhanced and a more efficient mass-to-energy ratio was achieved.

No subsidence was evident at the surface of the melt as seen in Test 1, although a void space was found at the top of the block between the electrodes. The void space was caused by cooling of the surface glass and the subsequent formation of a cold cap over the melt area. The high viscosity of the glass contributed to the formation of the cold cap, which caused the glass to adhere to the electrodes and bridge across the surface instead of slumping into a subsidence. Upon further investigation, small gas bubbles were visibly present in the glass product, confirming the molten soil was highly viscous. The glass and crystalline block exhibited physical characteristics similar to those produced in previous ISV tests, with the exception of the "lava-1ike" appearance caused by gases being trapped in the product. The interior of the vitrified block was relatively homogeneous, indicating the contaminants were mixed with the soil during melting. 

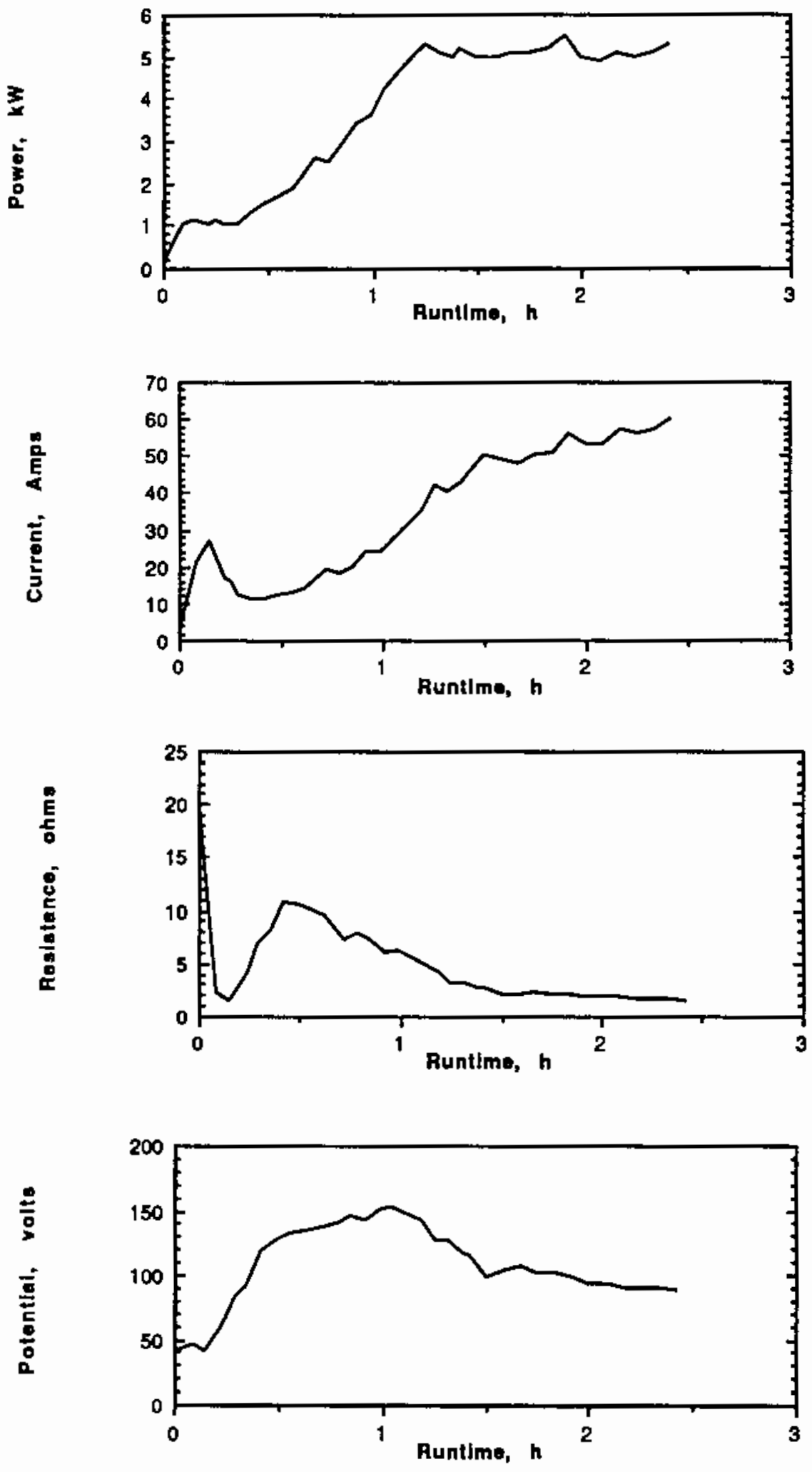

FIGURE 10. Electrical Data for ISV Processing of SRS Soil, Test 2 



\section{TEST RESULTS}

Following completion of the tests, analyses were conducted on 1) the vitrified products to determine their quality and durability, 2) Test 2 surrounding soil to determine the presence of any thermal transport effects, and 3) Test 1 off-gas emissions to obtain release information of the volatile compounds and organics. Due to the electrode failure encountered in Test 1 and the ensuing termination of the test prior to complete vitrification of the contaminated zone, no conclusive release rate information will be reported.

The analytical data provided in testing of SRS soil on a bench-scale indicates the successful vitrification of chemically-simulated soil similar to that found in seepage basins present at SRS.

\section{PRODUCT EVALUATION}

Samples of the vitrified product were subjected to the EP Tox test. This test measures the concentration of specific metals in leachate generated from immersing powdered, vitrified products in deionized water at room temperature for $24 \mathrm{~h}$. In general, the EP Tox test is used to determine the products compliance with regulatory requirements for final disposal. Results of the EP Tox test are listed in Table 4. The results obtained from the leach testing were considerably below those limits prescribed by the EPA.

IABLE 4. EP Tox Concentrations for the SRS Bench-Scale Tests

\begin{tabular}{ccccc} 
Contaminant & $\begin{array}{c}\text { Test } 1 \\
\text { Glas, } \mathrm{mg} / \mathrm{L}\end{array}$ & $\begin{array}{c}\text { Test } 2 \\
\text { Glass, mg/L }\end{array}$ & \multicolumn{2}{c}{$\begin{array}{c}\text { Max. Al lowed } \\
\text { EP Tox Conc., mg/L }\end{array}$} \\
$\mathrm{As}$ & $<0.01$ & $<0.1$ & 5.0 \\
$\mathrm{Ba}$ & $<0.1$ & $<0.1$ & 100.0 \\
$\mathrm{Cd}$ & 0.01 & 0.01 & 1.0 \\
$\mathrm{Cr}$ & $<0.01$ & $<0.01$ & 5.0 \\
$\mathrm{~Pb}$ & $<0.01$ & $<0.01$ & 5.0 \\
$\mathrm{Hg}$ & $<0.0004$ & $<0.0004$ & 0.2 \\
$\mathrm{Se}$ & 0.01 & 0.01 & 1.9 \\
$\mathrm{Ag}$ & $<0.1$ & $<0.1$ & 5.0
\end{tabular}


These results indicate the vitrified product would be an excellent waste form and would provide a long-term isolation of the radioactive and hazardous components present in the contaminated underground structures at the SRS.

\section{SURROUNDING SOIL}

Samples of the surrounding soil from Test 2 were taken to determine if any species had migrated outside the vitrified zone. Sampling locations were determined by the presence of thermal gradients originating from the heat generated in the molten material. Soil samples at the $400^{\circ} \mathrm{C}$ and $100^{\circ} \mathrm{C}$ isotherms (zones where the maximum temperature reached during or after operation was $400^{\circ} \mathrm{C}$ and $100^{\circ} \mathrm{C}$, respectively) and of ambient soil were analyzed by SW 846 Method 3050, "Acid Digestion of Sediments, Sludges, and Soils, " for the components added to the sludge. Method 3050 is an acid-digestion procedure used to prepare sediment, sludge, and soil samples for analysis by inductively coupled argon plasma spectroscopy (ICP). Table 5 presents the results of these analyses. Results of analyses performed on uncontaminated SRS soil

TABLE 5. Surrounding Soil Analyses

\begin{tabular}{|c|c|c|c|c|}
\hline Constituent & $\begin{array}{c}\text { Ambient } \\
\text { Isotherm, } \\
\text { ppm }\end{array}$ & $\begin{array}{c}100^{\circ} \mathrm{C} \\
\text { Isotherm, } \\
\text { ppm }\end{array}$ & $\begin{array}{c}400^{\circ} \mathrm{C} \\
\text { Isotherm, } \\
\text { ppm } \\
\end{array}$ & $\begin{array}{c}\text { Pretest } \\
\text { Soil } \\
\text { ppm } \\
\end{array}$ \\
\hline $\mathrm{Ag}$ & $<1$ & $<1$ & $<1$ & 1.6 \\
\hline As & $<1$ & $<1$ & $<1$ & $<1$ \\
\hline $\mathrm{Ba}$ & 30 & 31 & 25 & 54 \\
\hline $\mathrm{Cd}$ & 1 & $<1$ & 1 & 3.9 \\
\hline $\mathrm{Ce}$ & 50 & 50 & 40 & 61 \\
\hline $\mathrm{CN}^{-}$ & 1.2 & 52 & 0.93 & NA \\
\hline $\mathrm{Cr}$ & 4 & 4 & 4 & 23.2 \\
\hline $\mathrm{Cs}$ & $<500$ & $<500$ & $<500$ & 2.6 \\
\hline $\mathrm{Hg}$ & 12 & 1.2 & 1 & 1.06 \\
\hline $\mathrm{Ni}$ & $<10$ & $<10$ & $<10$ & 83.5 \\
\hline $\mathrm{Pb}$ & 3.6 & 4.2 & 5.2 & 6.3 \\
\hline $\mathrm{Sr}$ & 2 & 2 & 3 & 31.1 \\
\hline
\end{tabular}


prior to testing are also presented in Table 5. Samples taken of the uncontaminated SRS soil were analyzed by performing separate fusions in sodium peroxide and lithium metaborate and submitted for ICP-mass spectrometry analysis. As seen in Table 5, the pretest soil results are higher than the surrounding soil results due to the fact that the fusion preparation technique completely dissolved the base soil matrix, which allowed elemental determination of the material comprising the base soil. In contrast, the aciddigestion preparation technique removed only material that was leached onto the soil or that was present in the outermost layer of the soil particles. No migration of contaminants was evident at the sampling location. Analyses performed for cyanide using SW 846 Method 9010, "Total and Amenable Cyanide," reported a value of $50 \mathrm{ppm}$ in the $100^{\circ} \mathrm{C}$ isotherm, but this lone elevated analysis may be due to cross contamination resulting from the soil being excavated from the test container after Test 1 . Cyanide at this concentration or the spike concentration added to the soil is not considered a characteristic waste as described in WAC 173-303 (Washington Department of Ecology 1989).

\section{RETENTION OF RADIONUCLIDES AND HAZARDOUS CHEMICALS}

The efficiency of retaining or destroying hazardous chemicals and radionuclides by the ISV process can be expressed as a percent retention in the vitrified product. $1 \mathrm{t}$ is defined as follows:

$$
\% \text { Retention }=\left(1-M_{e} / M_{j}\right) \times 100
$$

where $\mathrm{M}_{\mathrm{e}}=$ mass of species released to the off gas, and

$M_{j}=$ mass of the species present in the sojt to be vitrified.

Species released during processing include those amounts present in the off-gas stream, any plateout that occurred in the head space of the system container or off-gas piping, and contamination caught in the insulation used to minimize cold cap formation.

Due to the inability to complete Test 1 and the amount of error introduced in excavating the simulated contaminated soil required for setup prior to Test 2, material balances required to calculate actual retentions were not 
able to be performed. Table 6 lists the expected percent retention in the vitrified soil for the hazardous and radioactive components present in the simulated soil. The expected retention reflects data obtained from previous ISV testing (Buelt et al. 1987; Hansen and FitzPatrick 1989; Buelt, Timnerman, and Westsik 19B9; Buelt and Freim 1986; Buelt and Bonner 19B9).

The burial depth of the contaminants has a direct effect on retention (Buelt, Timmerman, and Westsik 1989). Data from pilot-scale and large-scale testing (Buelt et al. 1987) routinely exhibit improved retention of species in the ISV block for larger scale applications.

TABLE 6. Contaminant Retention in the Vitrified Soi1

\begin{tabular}{cl} 
Constituent & \multicolumn{1}{c}{$\begin{array}{c}\text { Expected } \\
\text { Percent } \\
\text { Percent Retention }\end{array}$} \\
\cline { 2 - 2 } $\mathrm{Cr}$ & 99.9 \\
$\mathrm{Hg}$ & 46 \\
$\mathrm{~Pb}$ & 97 \\
$\mathrm{Cs}$ & 99.3 \\
$\mathrm{Sr}$ & 99.99 \\
$\mathrm{Co}$ & 99 \\
$\mathrm{As}$ & $70-85$ \\
$\mathrm{Cd}$ & 75 \\
$\mathrm{Cu}$ & $(\mathrm{a})$ \\
$\mathrm{F}$ & 99 \\
$\mathrm{Ni}$ & 99.9 \\
$\mathrm{Ce}$ & 99 \\
$\mathrm{Ba}$ & 99.9 \\
$\mathrm{Cl}$ & $98-99$ \\
$\mathrm{Ag}$ & $(\mathrm{a})$ \\
$\mathrm{NO}{ }_{3}$ & 99 \\
$\mathrm{PO}$ & 98 \\
$\mathrm{SO}_{4}$ & $91-99$ \\
&
\end{tabular}

(a) Denotes constituents not previously tested. 
The small quantity of radionuclide and hazardous constituents not retained in the melt is completely removed from the gaseous effluents before being exhausted to the atmosphere. The efficiency of the off-gas system is measured by a decontamination factor (DF), which is defined as:

$$
D F=M_{j} / M_{e}
$$

where $\mathrm{M}_{\mathrm{e}}=$ mass of species released to the off gas, and $M_{j}=$ mass of the species present in the soil to be vitrified.

The $D F$ is another way of expressing retention, where $R=1-1 / D F$. The system DF, which includes contaminant retention in the melt and removal by the offgas system, is an overall measure of the ISV system efficiency. Typical DFs for the off-gas system, the overall system DFs, and percent retention of the overall system are 1 isted in Table 7. Analyses performed on the surrounding soil and the glass product, along with expected off-gas removal efficiencies, indicate the effective retention of all contaminant species present in the test.

TABLE 7. Decontamination Factors of Metals (Buelt, Timmerman, and Westsik 1989)

\begin{tabular}{|c|c|c|c|}
\hline Iype of Meta] & $\begin{array}{l}\text { Off-Gas } \\
\text { Ireatment DF }\end{array}$ & $\begin{array}{l}\text { Overall } \\
\text { DF } \\
\end{array}$ & $\begin{array}{l}\text { Overall } \\
\text { Percent } \\
\text { Retention }\end{array}$ \\
\hline Particulates & & & \\
\hline $\mathrm{Sr}, \mathrm{Pu}, \mathrm{U}, \mathrm{Cr}$ & $10^{5}$ & $10^{10}$ & 99.99999999 \\
\hline Semivolatiles & & & \\
\hline $\begin{array}{l}\text { Co, Cs, Tc } \\
\text { Volatiles }\end{array}$ & $10^{4}$ & $10^{6}$ & 99.9999 \\
\hline $\mathrm{Cd}, \mathrm{Pb}, \mathrm{Hg}$ & $10^{4}$ & $10^{5}$ & 99.999 \\
\hline
\end{tabular}





\section{POTENTIAL PROCESSING ENHANCEMENT TECHNIQUES FOR SRS SOILS}

As can be seen by the very low alkaline concentrations $(<0.2 \mathrm{wt} \%)$, the SRS soils are extremely weathered. Alkaline elements such as sodium and potassium are essential for the ISV process because they are the charge carriers that conduct the electrical current that generates the soil-melting heat during the process. Therefore, at these low alkaline concentrations, special processing enhancement techniques are required to vitrify the alkalidepleted soil. Two such techniques were tested, as described in this report, with varying success. The first, the placement of a starter layer of easily melted material over the SRS soil met with limited success. The process continued to melt preferentially outward without achieving a significant downward penetration into the SRS soil. The second technique required premixing of alkali materials into the soil, which was highly successful. However, premixing the soils with alkali constituents detracts from many advantages of the process of vitrifying the contaminants in place without pretreatment. Consequently, this report recommends developing and testing alternative ways of vitrifying SRS soil in place without prior removal for alkali mixing.

Two alternatives are recommended to be evaluated and tested for alkalidepleted soils at the Savannah River Site. They include:

- introduction of passive electrodes, and

- injection of soluble alkaline solutions.

Introduction of passive electrodes involves the intentional placement of iron-based metals in the startup layer. The metal will melt and remain at the bottom of the molten vitrified zone. This has the effect of diverting the electrical current near the bottom of the molten mass, as shown in Figure 11. The molten metal thus acts as a "passive" electrode that diverts electrical current and power near the bottom of the melt by providing a path of lower resistance to the electrodes. This creates higher melting temperatures, which should enhance the downward melting rate. In addition, the molten metal layer is in direct contact with the alkali-depleted soil being vitrified. The superior thermal conductivity of the molten metal enhances heat transfer to the alkaline-depleted soil, thereby assisting in the downward melting process. The combination of these two effects has been shown to 




FIGURE 11. The Effect of a Molten Metal "Passive" Electrode on Electrical Current Distribution in the Melt

enhance downward melting rates of other types of soils (Buelt and Farnsworth 1990). This behavior is depicted in Figure 12, which demonstrates that for two bench-scale tests performed with high concentrations of metals (>10 wt\%), approximately twice the melting depth rate was achieved for the same energy input.

Pacific Northwest Laboratory is currently developing a self-feeding electrode technique that makes the introduction of passive electrodes possible (Buelt and Farnsworth 1990). As metals are encountered, the self-feeding electrodes can be withdrawn slightly from the bottom of the melt to avoid a direct electrical short. The influence of the passive electrodes can be controlled by the separation between the bottom of the graphite electrodes and the molten metal pool. The smaller the distance between the graphite electrodes and the molten metal pool, the greater the concentration of current will be near the bottom, and the greater the downward melting rate will be. 


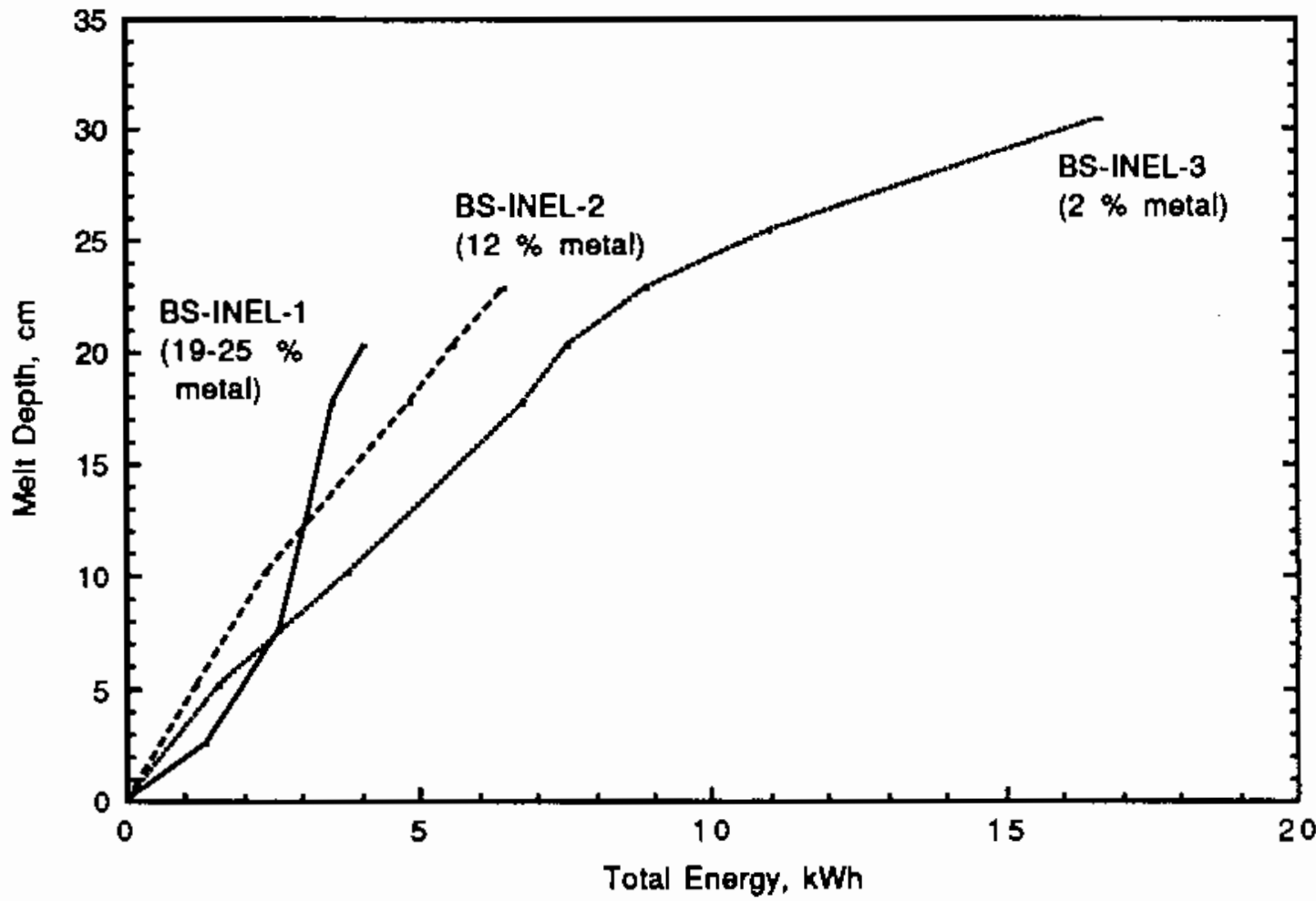

FIGURE 12. Melt Depth Versus Energy Input for Three Bench-Scale ISV Tests

The second technique involves injecting soluble alkaline fluxes into the soil prior to vitrification. The success of Test 2 described in this report demonstrates the feasibility of this approach. The onty remaining uncertainty with this approach is the ability to inject alkaline solutions into the soil in a controlled manner and to detect the extent of injection without additional sampling.

Injection of solutions underground is available with current technology (Phillips and Hinschberger 1989). The extent of injection could be detected by soil resistivity probes, since the alkali solutions are ionically conductive.

Additional testing of the two techniques on larger scales is recommended to further study the feasibility of treating contaminated SRS soil by the ISV process. 


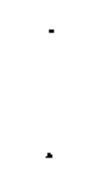




\section{REFERENCES}

Buelt, J. L., and S. T. Freim. 1986. Demonstration of In Situ Vitrification for Volume Reduction of Zirconia/Lime sludges. Prepared for Teledyne Wah Chang, Albany, Oregon, under Contract 2311205327.

Buelt, J. L., C. L. Timmeman, K. H. Oma, V. F. FitzPatrick, and J. G. Carter. 1987. In Situ Vitrification of Transuranic Waste: An Updated Systems Evaluation and Application Assessment. PNL-4800, Supp7. 1, Pacific Northwest Laboratory, Richland, Washington.

Buelt, J. L., C. L. Timmerman and J. H. Westsik, Jr. 1989. In Situ Vitrification: Test Results for a Contaminated Soil-Melting Process. PNLSA-15767, Supp7. 1, Pacific Northwest Laboratory, Richland, Washington.

Buelt, J. L., and W. F. Bonner, 1989. In Situ Vitrification: Test Results for a Contaminated Soil Melting Process. PNL-SA-16584, Pacific Northwest Laboratory, Richland, Washington.

Buelt, J. L., and R. K. Farnsworth. 1990. In Situ Vitrification of Soils Containing Various Metals. PNL-SA-17242, Pacific Northwest Laboratory, Richland, Washington.

Dunaway, J.K.W., W. F. Johnson, L. E. Kingley, R. V. Simmons, H. W. Bledsoe, and J. A. Smith. 1987. 07d TNX Seepage Basin. DPST-85-710, E. I. duPont de Nemours \& Co., Aiken, South Carolina.

Hansen, J., and V. FitzPatrick. 1989. "In Situ Vitrification: Heat and Immobilization are Combined for Soil Remediation." HAZMAT WORLD.

Looney, B. B., C. A. Eddy, M. Ramdeen, J. Pickett, V. Rogers, P. A. Shirley, and M. T. Scott. 1990. Geochemical and Physical Properties of Soils and Shallow Sediments at the Savannah River Site. WRSC-RP-90-0464, Westinghouse Savannah River Company, Aiken, South Carolina.

Odum, J. V., B. S. Christie, C. B. Fliermans, and I. W. Marine. 1987. 01d F-Area Seepage Basin. 1987. DPST-85-692, E. I. duPont de Nemours \& Co., Aiken, South Carolina.

Pekkala, R. 0., C. E. Jewe11, W. G. Homes, and I. W. Marine. 1987a. Reactor Seepage Basins. DPST-85-707, E. I. duPont de Nemours \& Co., Aiken, South Carolina.

Pekkala, R. 0., C. E. Jewell, W. G. Holmes, R. V. Simmons, and I. W. Marine. 1987b. Ford Building Seepage Basin. DPST-85-709, E. I. duPont de Nemours \& Co., Aiken, South Carolina. 
Phillips, S. J., and S. T. Hinschberger. 1989. "Concurrent In Situ Treatment and Disposal of Low-Level Radioactive Waste: Technology Development." Radioactive Waste Management. British Nuclear Energy Society, London, England.

Washington Department of Ecology. 1989. Washington Administrative Code, Dangerous Waste Regulations, Chapter 173-303. Amended January 1989. 


\section{DISTRIBUTION}

No. of

Copies

\section{QFFSITE}

12 DOE/Office of Scientific and Technical Information

T. B. Hindman, DP- 12 DOE Office of Defense Programs GTN

Washington, DC 20545

H. F. Walter, EM-343

DOE Office of Waste Operations GTN

Washington, DC 20545

5 DOE Office of Environmental

Restoration and Waste Management

Forrestal Building

Washington, DC 20585

ATTN: C. R. Cooley, EM-55

T. D. Anderson, EM -442

C. Frank, EM-50

S. Prestwich, EM-52

S. P. Mathur, EM-54

J. Arthur

DOE Albuquerque Operations Office

P.0. Box 5400

A1buquerque, NM 87185

E. Maestas

DOE West Valley Project

P.0. Box 191

West Valley, NY 14171

3 DOE Idaho Operations Office

785 DOE P1 ace

Idaho Falls, ID 83402

ATTN: J. P. Hamric

M. W. Shupe

S. A. Morreale
No. of

Copies

W. T. Goldston

DOE Savannah River Operations office

P.0. Box A

Aiken, SC 2980]

M. J. Steindler, CMT-205

Argonne National Laboratory

9700 South Cass Avenue

Argonne, IL 60439

3 Battelle Memorial Institute

505 King Avenue

Columbus, $\mathrm{OH} 43201$

ATTN: W. A. Carbeiner

R. A. Nathan

Technical Library

L. D. Ramspott, L209

Lawrence Livermore National Laboratory

University of $\mathrm{Cal}$ ifornia

P.0. Box 808

Livermore, CA 94550

M.A.H. Reimus

Los Alamos National Laboratory

P.0. Box 1663

Los Alamos, NM 87545

4 Oak Ridge National Laboratory

P.0. Box Y

Oak Ridge, TN 37830

ATTN: G. K. Jacobs

L. J. Mezga

T. A. Row

B. P. Spalding

2 Sandia Laboratories

P.0. Box 5800

A1buquerque, NM 87185

ATTN: R. W. Lynch

Technical Library 
No. of

Copies

W. Howell

State of Idaho

Hazardous Material Bureau

1401 N. Hitton

Bojse, ID 83706

13 EG\&G Idaho

P.0. Box 1625

Idaho Falls, ID 83415

ATTN: S. 0. Bates

S. K. Merrill (5)

T. L. Clements

W. J. Quapp

J. L. Landon

D. Nickelson

R. M. Schletter

N. Smith

J. R. Weidner

J. R. 8erreth

Westinghouse Idaho Nuclear

Co., Inc.

P.0. Box 4000

Idaho Falls, ID 8340 I

5 Westinghouse Savannah River Company

Savannah River Site

Aiken, SC 29801

ATTN: J. Haselow

C. M. Jantzen

M. J. Plodinec

J. F. Sproul1, 704-S

J. Steele

J. M. Pope

West Valley Nuclear

Services Co.

P.0. Box 191

West Valley, NY 14171
No. of

Copies

\section{ONSITE}

4 Geosafe Corporation

Kirkland Park Place

303 Park Place, Suite 126

Kirkland, WA 98033

ATTN: V. F. FitzPatrick

C. L. Timmerman

J. G. Carter

S. C. Liikala

8 DOE Richland Operations Office

E. A. Bracken, A6-95

G. J. Bracken, A6-80

P. K. Clark, A6-80

P. F. Dunigan, A6-95

M. J. Furman, A6-80

R. E. Gerton, $A 6-80$

R. D. Izatt, A6-95

J. J. Sutey, A5-90

10 Westinghouse Hanford Company

J. W. Cammann, H4-54

K. R. Fecht, H4-56

R. E. Lerch, B2-35

H. E. McGuire, B2-35

J. L. Scott, R2-87

J. C. Sonnichsen, H4-54

D. A. Turner, R1-10

D. D. Wodrich, R1-48

R. D. Wojtasek, B2-15

B. A. Wolfe, L5-61 
No. of

Copies

\section{Pacific Northwest Laboratory}

C. E. Bigelow, P7-44

W. F. Bonner, P7-44

T. M. Brouns, P7-44

J. L. Buelt, P7-44

H. C. Burkholder, P7-41

B. E. Campbell, P7-44 (20)

C. C. Chapman, P7-41

T. T. Claudson, K1-66

R. K. Farnsworth, P7-44

R. D. Gibby, P7-44

W. 0 . Heath, P7-44

C. H. Kindle, P7-44

D. E. Knowlton, P7-40

S. S. Koegler, P7-44

W. L. Kuhn, P7-14

J. L. McElroy, P7-46

K. A. Parnel1, P7-14

M. E. Peterson, P7-44

T. D. Powe 11, P7-44

R. L. Richardson, P7-44

J. W. Shade, P8-37

C. M. Smith, P7-43

J. A. Stott lemyre, K6-78

L. E. Thompson, P7-44

Publishing Coordination

Technical Report Files (5) 


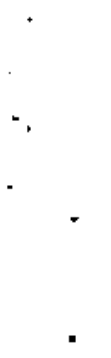

